\title{
Two new species of Rhinogobius (Gobiiformes: Oxudercidae) from Palawan, Philippines, with their phylogenetic placement
}

\author{
KEN MAEDA $^{1 *}$, CHUYA SHINZATO ${ }^{2}$, RYO KOYANAGI ${ }^{1,3}$, TAIGA KUNISHIMA $^{4}$, HIROZUMI KOBAYASHI ${ }^{5}$, \\ NORIYUKI SATOH ${ }^{1,6} \&$ HERMINIE P. PALLA ${ }^{7}$ \\ ${ }^{1}$ Okinawa Institute of Science and Technology Graduate University, 1919-1 Tancha, Onna, Okinawa 904-0495, Japan. \\ *Corresponding author. =" goby@live.jp; 이ttps://orcid.org/0000-0003-3631-811X \\ ${ }^{2}$ Atmosphere and Ocean Research Institute, The University of Tokyo, Chiba 277-8564, Japan. \\ (1) https://orcid.org/0000-0001-7843-3381 \\ 3 ○ https://orcid.org/0000-0002-9694-0288 \\ ${ }^{4}$ Wakayama Prefectural Museum of Natural History, 370-1 Funoo, Kainan, Wakayama 642-0001, Japan. \\ (1) https://orcid.org/0000-0002-2662-3842 \\ ${ }_{5}^{5}$ University of the Ryukyus, 1 Senbaru, Nishihara, Okinawa 903-0213, Japan. \\ (1) https://orcid.org/0000-0003-0718-5637 \\ ${ }^{6}$ (ㄴ https://orcid.org/0000-0002-4480-3572 \\ ${ }^{7}$ College of Fisheries and Aquatic Sciences, Western Philippines University - Puerto Princesa Campus, Puerto Princesa City, 5300 \\ Palawan, Philippines. (1) https://orcid.org/0000-0003-2080-6602
}

\begin{abstract}
Two new species of Rhinogobius found in streams on central part of Palawan Island, Philippines are described. The two new species, Rhinogobius estrellae and Rhinogobius tandikan share unique transverse rows of sensory papillae on the cheek with Rhinogobius similis Gill, 1859, but differ from the latter in fin ray counts, arrangement of the scales, etc. The two new species are distinguished from each other by the pectoral-fin ray count, the longitudinal- and predorsal-scale counts, and colouration of the body. Rhinogobius estrellae new species and $R$. tandikan new species have been found allopatrically in a stream within Malatgao River system flowing into the Sulu Sea and in the Cayulo River flowing into the South China Sea, respectively. The Malatgao River system is the southernmost habitat of the genus Rhinogobius. Rhinogobius similis had been considered as the only member of the most basal lineage of this genus, but our mitochondrial genome analysis suggested that the two new species are additional members of this lineage. They are considered to be relicts of their common ancestor with $R$. similis, which probably had a wider distribution.
\end{abstract}

Key words: goby, freshwater fish, taxonomy, phylogeny, mitochondrial genome

\section{Introduction}

Rhinogobius Gill is a genus of freshwater goby distributed in East and Southeast Asia, including continental waters from Russian Far East, Korean Peninsula, China to Vietnam, Laos, Thailand, and Cambodia, as well as islands including Sakhalin, Japan, Taiwan, Hainan, and the Philippines (Pietsch et al. 2001; Huang \& Chen 2007; Huang et al. 2016; Nagao Natural Environment Foundation 2021). The southernmost habitat of Rhinogobius reported with reliable information is South Central Coast in Vietnam, including Da Nang to Ninh Tuang (Serov et al. 2006; Maeda et al. 2015) and Cambodia (Nagao Natural Environment Foundation 2021). In the Philippines, three species are known from Luzon Island (Herre 1927, 1934).

The gobies of this genus inhabit streams, rivers, reservoirs, lakes, ponds, creeks, marshes, and estuaries (Kondo et al. 2013; Suzuki et al. 2019). Many species in coastal areas are known to be amphidromous, with larvae developing in marine habitats during their pelagic larval phase (Tsunagawa \& Arai 2008; Maeda \& Tachihara 2010; Iida et al. 2017; Liao et al. 2020), while many other species are freshwater residents with a fluvial or lentic life cycle (Mizuno 1960; Hirashima \& Tachihara 2000; Tsunagawa et al. 2010).

We found two species of Rhinogobius in streams in the central part of Palawan Island, western Philippines. 
Palawan is located out of the known range of this genus and our findings extended the range southward. In the present study, the two species are described as new species and phylogenetic relationships among the genus Rhinogobius is analysed with mitochondrial genome sequences.

\section{Materials and methods}

Collection of samples. Specimens were collected using hand nets. After being euthanized with 2-phenoxyethanol solution, their right pectoral fins were cut off and preserved in $99.5 \%$ ethanol for mitochondrial DNA analysis, and then gobies were fixed in $10 \%$ formalin and preserved in $70 \%$ ethanol for morphological examination. Sampling was conducted according to the laws and regulations of the Philippines. Collections in Palawan were performed with Wildlife Gratuitous Permits (No. 2016-09, 2018-16) provided by the Palawan Council for Sustainable Development and with Prior Informed Consent Certificates from all relevant cities, municipalities, and barangays [villages]. The procedures used to handle fish specimens in this study were approved by the Animal Care and Use Committee of the Okinawa Institute of Science and Technology Graduate University.

Morphological examination. Measurements and counts were taken from the left side of each fish. Measurements were made point to point to the nearest $0.1 \mathrm{~mm}$, using a vernier calliper under a stereomicroscope, and were expressed as a percentage of standard length (SL). Measurements and counts followed Nakabo (2002), with the following modifications. Body depths were measured at the pelvic- and anal-fin origins. The first and second dorsal- and anal-fin lengths were measured from the anterior origin of each fin to the farthest point when the fin was adpressed. Longitudinal scale counts were the number of oblique (anterodorsal to posteroventral) scale rows taken from just the dorsal to the upper attachment of the opercular membrane posteriorly to the mid-base of caudal fin. Transverse scale counts were the number of scales from origin of the second dorsal fin downward and backward to the base of the anal fin. Transverse scales on the caudal peduncle were counted along a vertical zigzag line around the narrowest point of the caudal peduncle from a scale on the dorsal midline to a scale on the ventral midline. Abbreviations pertaining to the cephalic sensory pore system followed Akihito et al. (1984). Number of vertebrae and pattern of interdigitation of the dorsal-fin pterygiophores and neural spines (P-V) were observed from the radiographs of the holotype and nine paratypes for each species. P-V was expressed with the method of Akihito et al. (1984). Symbolic codes used to represent collections and institutions follow Sabaj (2019). Colour in life was described based on photographs of the fish taken in situ including those of individuals which were not collected.

Mitochondrial DNA analysis. The total genomic DNA of 26 specimens of nine species of Rhinogobius including the two new species and two specimens of Tridentiger kuroiwae Jordan \& Tanaka (outgroup) was extracted from the right pectoral fins preserved in $99.5 \%$ ethanol, using a DNeasy Blood \& Tissue Kit (Qiagen, Hilden, Germany) or a Maxwell RSC Blood DNA Kit (Promega, Fitchburg, Wisconsin, USA).

Whole genome shotgun sequencing libraries were prepared using a KAPA HyperPlus Kit for PCR-free workflows (KAPA Biosystems, Wilmington, Massachusetts, USA) or NEBNext Ultra II FS DNA Library Prep Kit for Illumina (New England BioLabs, Ipswich, Massachusetts, USA). The extracted genomic DNA was enzymatically fragmented into pieces of 200-1000 bp using KAPA Frag (KAPA Biosystems). After repairing the protruding ends and A-tailing, sequencing adaptors were ligated onto both ends of the DNA fragments. Shotgun libraries were then sequenced on one of the following instruments and reagents together with other fish libraries which were not used in this study, following the manufacturer's instructions: Illumina HiSeq 2500 sequencer (Illumina, San Diego, California, USA) in Rapid Run mode using a HiSeq Rapid Cluster Kit v2-Paired-End (Illumina) and a HiSeq Rapid SBS Kit v2 (Illumina) or in high output mode using HiSeq PE Cluster Kit v4 cBot and HiSeq SBS Kit v4 (Illumina), Illumina HiSeq 4000 sequencer using HiSeq 3000/4000 Cluster Kit (Illumina) and HiSeq 3000/4000 SBS Kit (Illumina), or Illumina NovaSeq 6000 sequencer using NovaSeq 6000 SP Reagent Kit v1.0 (Illumina).

Sequencing data from each library were assembled using IDBA_UD assembler version 1.1.1 (Peng et al. 2012) with different kmer lengths $(60,80,100)$. Identification of complete mitochondrial genomes from assembled contigs was performed by: 1) comparing them with the complete mitochondrial genome of Stiphodon alcedo Maeda, Mukai \& Tachihara (accession: AB613000.1) (BLASTN e-value B 1e-100), and by 2) confirming that $100 \mathrm{bp}$ of both head and tail DNA sequences of a contig were identical, indicating that the sequence was circular. Complete mitochondrial genomes were aligned using MAFFT v7.244 (Katoh \& Standley 2013) and all positions with gaps were removed using trimAl (Capella-Gutiérrez et al. 2009). Approximately 33,809 to 698,285 coverages of 
sequencing data were used for mitochondrial genome assembly for each sample. We performed molecular phylogenetic analyses of our aligned mitochondrial genomes along with mitochondrial genome sequences of $R$. cliffordpopei (Nichols), $R$. duospilus (Herre), and R. leavelli (Herre) from the International Nucleotide Sequence Database published by Tan et al. (2020), Wang et al. (2019), and Zhang \& Shen (2019), using the GTR+I+Gamma model, and performed a maximum likelihood (ML) analysis using RAxML version 8.2.3 (Stamatakis, 2014) with 100 bootstrap replicates. The assembled mitochondrial genome sequences with gene annotations are available in the DNA Data Bank of Japan (DDBJ) under accession numbers: LC648291-LC648316, LC653489, and LC653490. Accession numbers for each individual are given in Table 1. Collection data for outgroup specimens are as follows: Tridentiger kuroiwae, URM-P 48971, Okinawa Island, 29 January 2015, coll. K. Maeda; URM-P 48995, Okinawa Island, 18 February 2015, coll. K. Maeda.

TABLE 1. List of accession numbers of mitochondrial genome sequences analysed in this study.

\begin{tabular}{|c|c|c|c|c|}
\hline Species & $\begin{array}{l}\text { Catalogue number } \\
\text { of voucher } \\
\text { specimen }\end{array}$ & $\begin{array}{l}\text { Accession number } \\
\text { for assembled } \\
\text { mitochondrial } \\
\text { genome sequence }\end{array}$ & $\begin{array}{l}\text { Length of } \\
\text { mitochondrial } \\
\text { genome } \\
\text { sequence (bp) }\end{array}$ & Remarks \\
\hline Rhinogobius estrellae & WPU-PPC-P 50 & LC648291 & 16682 & Paratype \\
\hline Rhinogobius estrellae & URM-P 49296 & LC648292 & 16682 & Paratype \\
\hline Rhinogobius estrellae & URM-P 49297 & LC648293 & 16504 & Paratype \\
\hline Rhinogobius estrellae & URM-P 49298 & LC648294 & 16504 & Paratype \\
\hline Rhinogobius estrellae & NSMT-P 140091 & LC648295 & 16505 & Holotype \\
\hline Rhinogobius estrellae & URM-P 49300 & LC648296 & 16504 & Paratype \\
\hline Rhinogobius tandikan & NSMT-P 140093 & LC648297 & 16691 & Holotype \\
\hline Rhinogobius tandikan & URM-P 49316 & LC648298 & 16690 & Paratype \\
\hline Rhinogobius tandikan & URM-P 49317 & LC648299 & 16918 & Paratype \\
\hline Rhinogobius tandikan & URM-P 49318 & LC648300 & 16690 & Paratype \\
\hline Rhinogobius similis & URM-P 49153 & LC648301 & 16641 & \\
\hline Rhinogobius similis & URM-P 49147 & LC648302 & 16499 & \\
\hline Rhinogobius similis & URM-P 49148 & LC648303 & 16499 & \\
\hline Rhinogobius similis & URM-P 49149 & LC648304 & 16499 & \\
\hline Rhinogobius flumineus & URM-P 49561 & LC648305 & 16504 & \\
\hline Rhinogobius flumineus & URM-P 49562 & LC648306 & 16503 & \\
\hline Rhinogobius yaima & URM-P 48739 & LC648307 & 16500 & Paratype \\
\hline Rhinogobius yaima & URM-P 48741 & LC648308 & 16500 & Paratype \\
\hline Rhinogobius yonezawai & URM-P 48726 & LC648309 & 16500 & \\
\hline Rhinogobius yonezawai & URM-P 48539 & LC648310 & 16500 & \\
\hline Rhinogobius brunneus & URM-P 49161 & LC648311 & 16500 & \\
\hline Rhinogobius brunneus & URM-P 49162 & LC648312 & 16500 & \\
\hline Rhinogobius sp. MO & URM-P 49014 & LC648313 & 16499 & \\
\hline Rhinogobius sp. MO & URM-P 49494 & LC648314 & 16499 & \\
\hline Rhinogobius nagoyae & URM-P 48290 & LC648315 & 16498 & \\
\hline Rhinogobius nagoyae & URM-P 48289 & LC648316 & 16499 & \\
\hline Rhinogobius duospilus & - & MH127918 & 16496 & Tan et al. (2020) \\
\hline Rhinogobius cliffordpopei & - & KT357638 & 16525 & Wang et al. (2019) \\
\hline Rhinogobius leavelli & - & MH729000 & 16499 & Zhang \& Shen (2019) \\
\hline Tridentiger kuroiwae & URM-P 48971 & LC653489 & 16501 & \\
\hline Tridentiger kuroiwae & URM-P 48995 & LC653490 & 16501 & \\
\hline
\end{tabular}




\section{Results}

Rhinogobius estrellae Maeda, Kunishima \& Palla, new species

[New English name: Estrella goby]

(Figs. 1-5; Tables 2-6)

Material examined. Eight males and 16 females from Narra, Palawan Island in the Philippines.

Holotype. NSMT-P 140091, male (40.6 mm SL), Estrella Falls, 13 May 2016, coll. K. Maeda, T. Kunishima, and H. P. Palla.

Paratypes. NSMT-P 140092, female (38.9 mm SL), same data as holotype; URM-P 49295-49301, 1 male (40.7 $\mathrm{mm} \mathrm{SL}$ ) and 6 females (36.1-40.9 mm SL), same data as holotype; URM-P 49302, female (43.0 mm SL), creek in front of the Estrella Village Barangay Hall, 28 May 2018, coll. K. Maeda, H. Kobayashi, and H. P. Palla; URM-P 49303-48306, 2 males (37.8-39.6 mm SL) and 2 females (36.4-45.3 mm SL), Estrella Falls, 28 May 2018, coll. K. Maeda, H. Kobayashi, and H. P. Palla; WPU-PPC-P 50-54, 1 male (37.5 mm SL) and 4 females (35.5-41.1 mm SL), same data as holotype; WPU-PPC-P 55-59, 3 males (37.3-38.4 mm SL) and 2 females (33.2-37.8 mm SL), Estrella Falls, 28 May 2018, coll. K. Maeda, H. Kobayashi, and H. P. Palla.

Diagnosis. Pectoral fin with 14-16 rays (usually 15 rays). Nape and posterior part of occipital region covered by cycloid scales; scaled area extending anteriorly to around a vertical line through posterior margin of preopercle or a little posterior to this line. Longitudinal scales 27-31, predorsal scales 3-11. Number of vertebrae 26. Cephalic sensory pore system usually with $\mathrm{B}^{\prime}, \mathrm{C}, \mathrm{D}(\mathrm{S}), \mathrm{E}, \mathrm{F}, \mathrm{H}^{\prime}, \mathrm{K}^{\prime}, \mathrm{L}^{\prime}, \mathrm{M}^{\prime}, \mathrm{N}$, and $\mathrm{O}^{\prime}$, but often lacking one or both side(s) of pore E. Transverse rows of sensory papillae on cheek. In preservative, lateral and dorsal sides of body with dark brown mesh-like markings, snout and cheek with three dark brown stripes, and pectoral fin with dark brown band vertically across proximal part of the upper and middle rays except lower 2-6 rays. In life, upper and middle parts of pectoral-fin base with bright white vertical band.
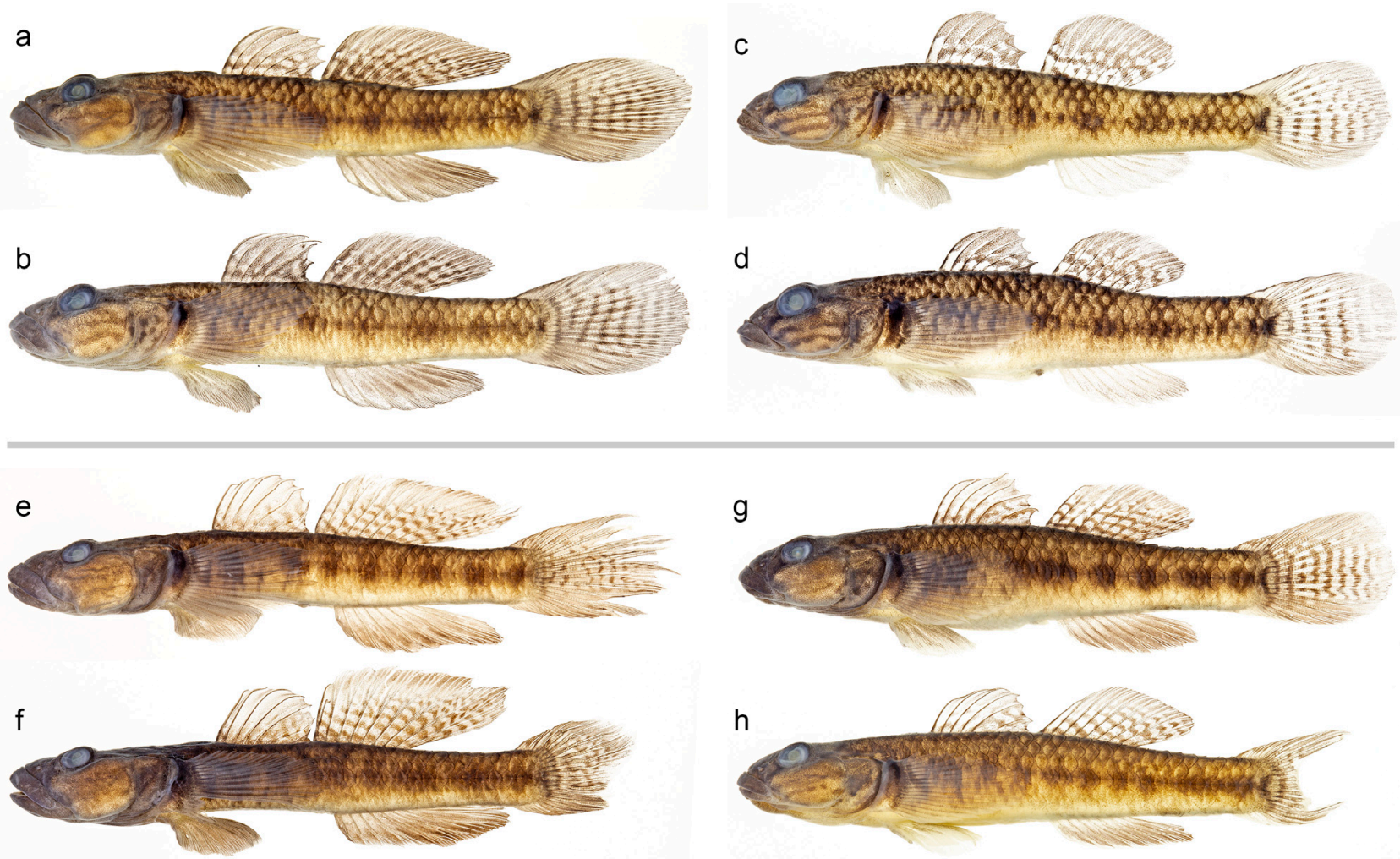

FIGURE 1. Preserved specimens of Rhinogobius estrellae (a-d, paratypes) and Rhinogobius tandikan (e-h, paratypes). Specimens in the left side are males, the right side are females. a, URM-P 49305, $39.6 \mathrm{~mm}$ SL; b, WPU-PPC-P 55, 38.4 mm SL; c, URM-P 49296, 36.1 mm SL; d, URM-P 49306, 36.4 mm SL; e, URM-P 49314, 46.9 mm SL; f, URM-P 49315, 46.5 mm SL; g, URM-P 49318, 45.2 mm SL; h, URM-P 49320, 37.9 mm SL (photo by K. Maeda). 
Description. Body nearly cylindrical anteriorly and somewhat compressed posteriorly. Head depressed and larger in male than female (head length 33.5-36.0 vs 30.3-32.9\% of SL; Fig. 3). Eyes located dorsolaterally. Mouth terminal and oblique with thick upper and lower lips. Anterior tips of upper and lower jaws almost even or upper jaw slightly protruding beyond lower jaw. Posterior end of upper jaw always exceeding a vertical line through anterior margin of eye. Mouth larger in male than female (upper-jaw length 14.1-16.1 vs 10.5-11.9\% of SL; Fig. 3). Anterior nostril short tubular, posterior nostril a pore. Cephalic sensory pore system usually with B', C, D(S), E, F, H', K', and $\mathrm{L}^{\prime}$ in oculoscapular canal and $\mathrm{M}^{\prime}, \mathrm{N}$, and $\mathrm{O}^{\prime}$ in preopercular canal, but 5/24 specimens lacking one pore $\mathrm{C}, 2 / 24$ specimens lacking both pores $\mathrm{C}, 7 / 24$ specimens lacking one pore E, 5/24 specimens lacking both pores E, 3/24 specimens having pore $\mathrm{G}$ on one side, and 1/24 specimens lacking one pore $\mathrm{N}$. One specimen having an additional single pore anterior to another single pore D. Arrangement of cutaneous sensory papillae of head shown in Fig. 4. Cheek having two longitudinal rows of papillae and 4-6 transverse rows both between eye and upper longitudinal row and between upper and lower longitudinal rows. Vertebrae $10+16=26(n=9)$ or $11+15=26(n=1)$, P-V 3/II II I I $0 / 9(n=9)$ or $3 /$ II I II II 0/9 $(n=1)$.

First dorsal fin usually with six spines supported by six pterygiophores, but $1 / 24$ specimen with seven spines supported by seven pterygiophores. Second dorsal fin usually with one spine and eight soft rays, but 3/24 specimens with one spine and seven soft rays. First- and second-dorsal-fin bases separated each other by a small interval (0.3-3.9\% of SL). First dorsal fin rounded, usually almost semi-circular; posterior tips of fin (usually tips of fourth to sixth spines) not reaching second dorsal fin origin $(n=13)$, just touching base of second-dorsal-fin spine ( $n=6$ ), or exceeding base of second-dorsal-fin spine but not reaching base of first soft ray of second dorsal fin ( $\mathrm{n}=5$ ). Anal fin usually with one spine and eight soft rays, but 3/24 specimens with one spine and seven soft rays and 2/24 specimens with one spine and nine soft rays. Caudal fin with 17 segmented rays, including $12(n=3), 13(n=9)$, or $14(\mathrm{n}=12)$ branched rays; posterior margin rounded. Male having larger second dorsal, anal, and caudal fins than female (second-dorsal-fin length 34.6-38.7 vs 27.7-30.2\% of SL, anal-fin length 31.3-33.7 vs 24.2-29.3\% of SL, and caudal-fin length 28.6-31.7 vs $24.4-28.0 \%$ of SL; Fig. 3). Pectoral fin with 14-16 rays (usually 15 rays) (Table 2). Pelvic fin with one spine and five soft rays; pelvic fins joined together to form a cuplike disk with fleshy bilobed frenum. Posterior tip of pelvic fin located below middle of first-dorsal-fin base.

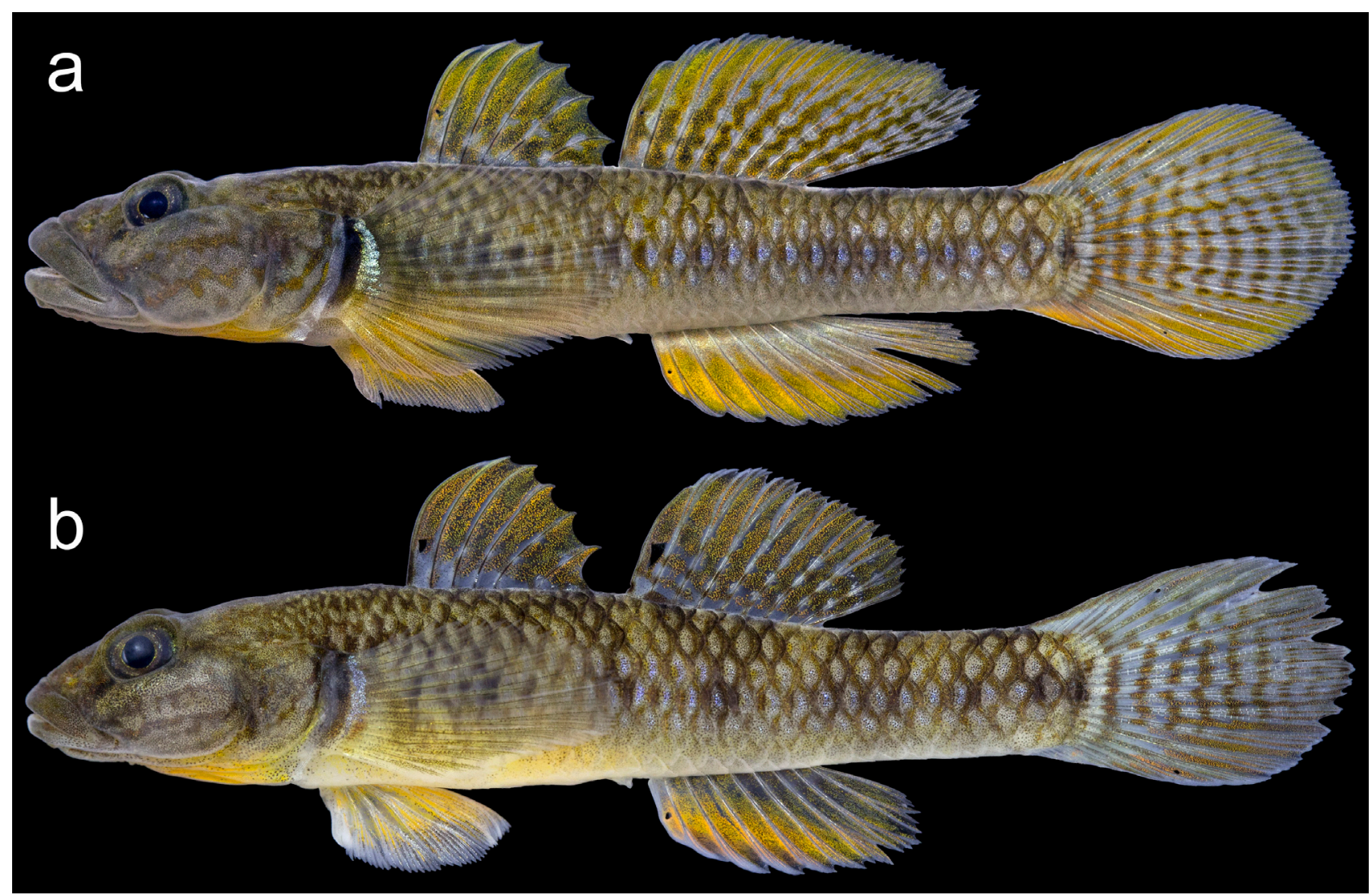

FIGURE 2. Rhinogobius estrellae. immediately after fixation. a, NSMT-P 140091, holotype, male, 40.6 mm SL; b, URM-P 49297, paratype, female, $37.5 \mathrm{~mm}$ SL (photo by K. Maeda). 
TABLE 2. Pectoral-fin ray counts of Rhinogobius estrellae and Rhinogobius tandikan.

\begin{tabular}{lllll}
\hline & 14 & 15 & 16 & 17 \\
\hline Rhinogobius estrellae & 2 & 19 & 3 & - \\
Rhinogobius tandikan & - & - & 16 & 13 \\
\hline
\end{tabular}

Ctenoid scales covering lateral side of body and dorsal and ventral sides of caudal peduncle. Nape and posterior part of occipital region covered by cycloid scales; scaled area extending anteriorly around vertical line through posterior margin of preopercle (above pore $\mathrm{H}^{\prime}$ ) or to a little posterior to this line (above area between pores $\mathrm{H}^{\prime}$ and $\mathrm{K}^{\prime}$ ). Other regions in head naked. Belly and first-dorsal-fin base covered with cycloid scales. A few cycloid scales also occurring on trunk behind pectoral fin, along bases of second dorsal, anal, and caudal fins, and on proximal part of caudal fin. Pectoral-fin base and breast (prepelvic area) probably naked (at least invisible without staining by arizarin red; see Suzuki et al., 2016). Longitudinal scales 27-31 (usually 28-30), transverse scales 8-10 (usually 9), transverse scales in caudal peduncle always 7, and predorsal scales 3-11 (Tables 3-5).

TABLE 3. Longitudinal scale counts of Rhinogobius estrellae and Rhinogobius tandikan.

\begin{tabular}{lllllllll}
\hline & 27 & 28 & 29 & 30 & 31 & 32 & 33 & 34 \\
\hline Rhinogobius estrellae & 1 & 6 & 11 & 5 & 1 & - & - & - \\
Rhinogobius tandikan & - & - & 2 & 11 & 12 & 3 & - & 1 \\
\hline
\end{tabular}

TABLE 4. Transverse scale counts of Rhinogobius estrellae and Rhinogobius tandikan.

\begin{tabular}{llll}
\hline & 8 & 9 & 10 \\
\hline Rhinogobius estrellae & 2 & 21 & 1 \\
Rhinogobius tandikan & 2 & 16 & 11 \\
\hline
\end{tabular}

TABLE 5. Predorsal scale counts of Rhinogobius estrellae and Rhinogobius tandikan.

\begin{tabular}{llllllllllll}
\hline & 3 & 4 & 5 & 6 & 7 & 8 & 9 & 10 & 11 & 12 & 13 \\
\hline Rhinogobius estrellae & 1 & 2 & 4 & 4 & 3 & 4 & 2 & 3 & 1 & - & - \\
Rhinogobius tandikan & - & - & 1 & - & 2 & 3 & 6 & 6 & 4 & 5 & 2 \\
\hline
\end{tabular}

Colour in preservative (Fig. 1): Background of head and body cream. Head with three dark brown stripes; upper one running on snout and connecting upper lip and eye; lower two running diagonally across cheek and connecting upper lip and posterior margin of preopercle. These stripes often broken-up with gaps, branches, and additional dots. Posterior margin of opercle fringed by narrow dark brown vertical band. Pectoral-fin base dark brown with thin, whitish vertical line along bases of middle and ventral rays. Scales on dorsal and lateral sides of body having dark brown margins forming mesh-like patterns. Darkness of scale margins variable and body often showing four or five dark brown saddles from trunk to caudal peduncle. First and second dorsal fins greyish brown with multiple transparent or pale grey spots on proximal and middle parts. Anal fin pale grey or greyish brown, often darker in males. Caudal fin pale grey or greyish brown with 6-10 dark brown vertical bands, but ventral part lacking these bands. Pectoral fin pale grey or greyish brown with a dark brown vertical band proximally on upper and middle parts. Pelvic fin pale grey or greyish brown.

Colour in life (Fig. 5): Background of head and body pale reddish- or yellowish grey but more whitish on ventral side; ventral surface of head and belly often tinged with orange. Dark brown markings on head and body described in "colour in preservative" present but more reddish. Background of cheek and opercular region often tinged with greyish blue. Pectoral-fin base black with a bright white vertical band posteriorly on upper to middle parts, and often tinged with greyish blue anteriorly. Background of body tinged with sky blue. First and second dorsal fins reddish brown or orange with many white spots on proximal and middle parts. Anal fin reddish brown or orange but proximal and posterior parts greyish blue. Caudal fin reddish brown or orange with 6-10 translucent or white transverse bands on middle part. Pectoral fin translucent often lightly tinged with orange, and proximal parts of some ventral rays white. Pelvic fin pale orange proximally and light grey or greyish blue distally. 

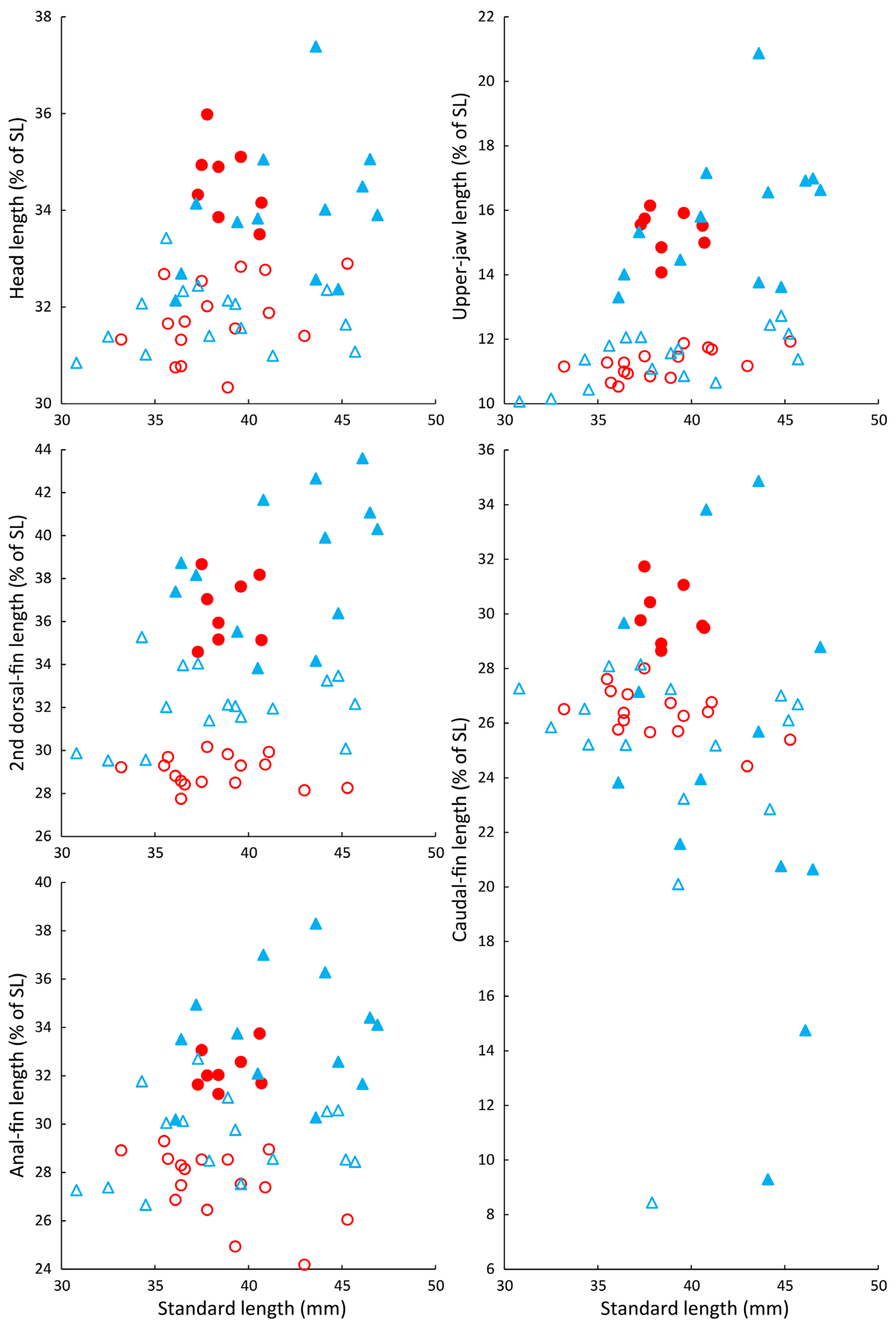

FIGURE 3. Head length, upper-jaw length, second dorsal-fin length, anal-fin length, and caudal-fin length of Rhinogobius estrellae (red circles) and Rhinogobius tandikan (blue triangles). Solid and open symbols represent males and females, respectively. 


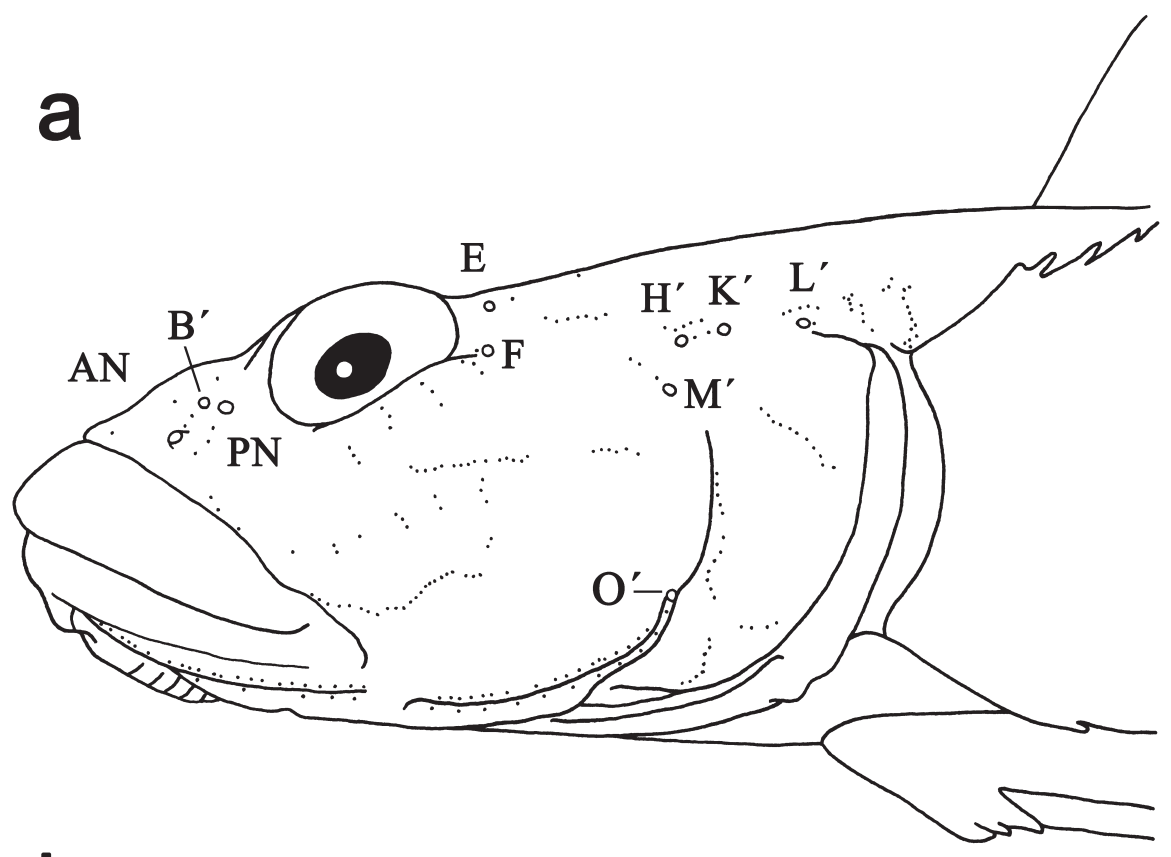

b
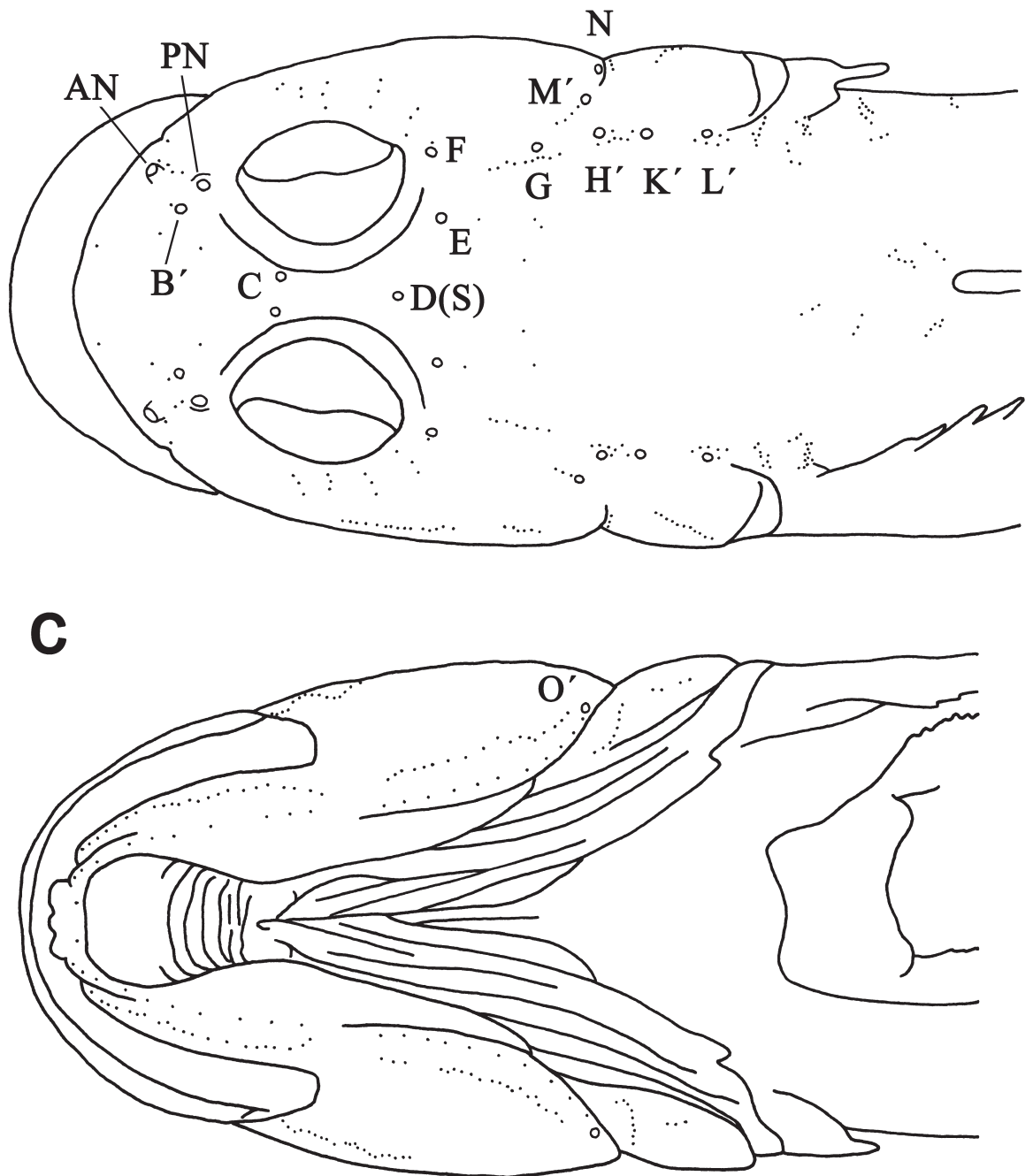

FIGURE 4. Arrangement of cephalic sensory pores and cutaneous sensory papillae in Rhinogobius estrellae (NSMT-P 140091, holotype). a, lateral view; b, dorsal view; c, ventral view. AN, anterior naris; PN, posterior naris. 


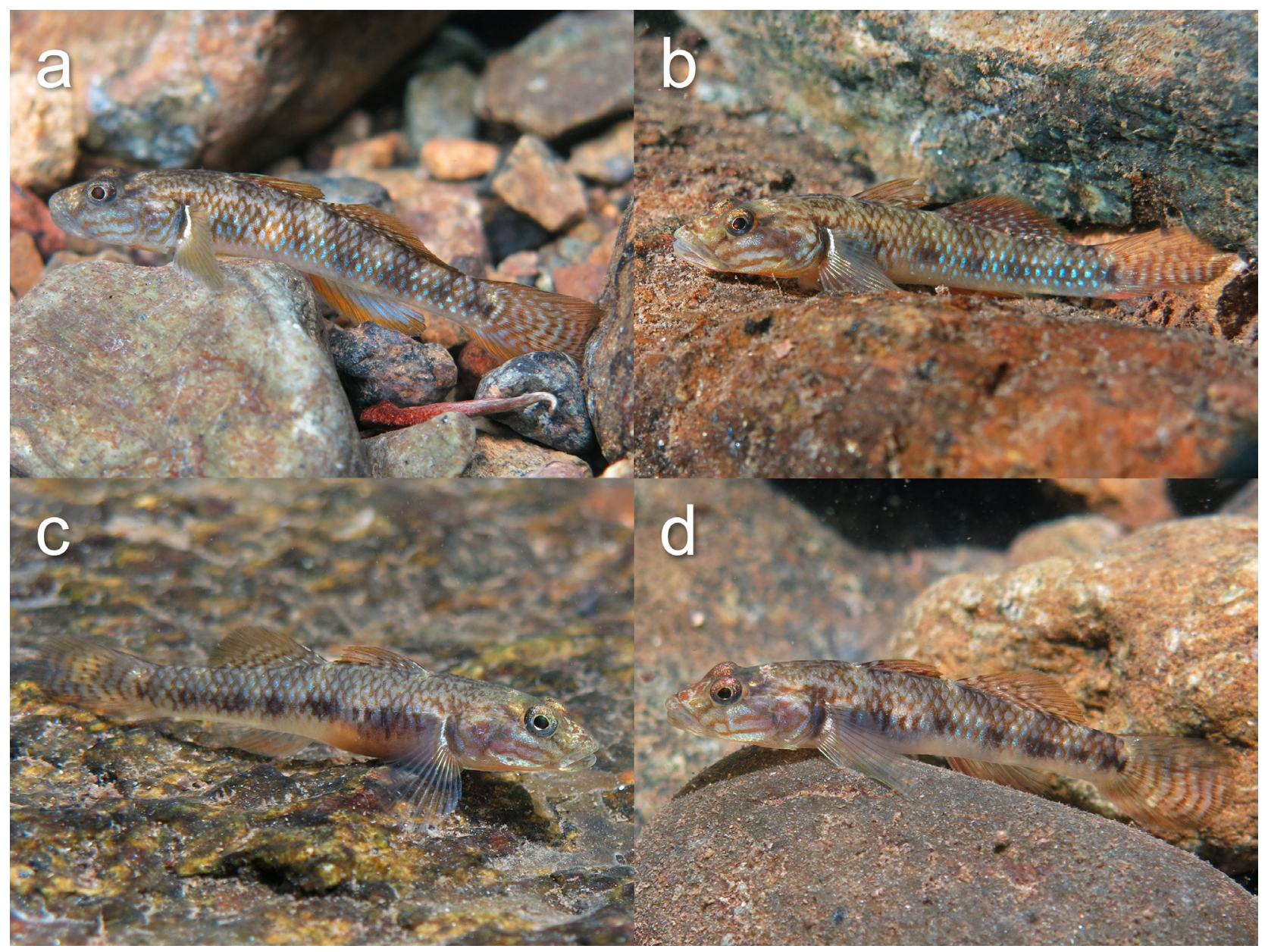

FIGURE 5. In situ underwater photographs of Rhinogobius estrellae in Estrella Falls, Palawan. a, male, 28 May 2018; b, male, 13 May 2016; c and d, females, 13 May 2016 (photo by K. Maeda).

Distribution. Rhinogobius estrellae is endemic to Palawan Island, Philippines. Most of the specimens examined were collected from a pool and the lower reaches of a stream below the Estrella Falls (9 $\left.21^{\circ} 26^{\prime \prime} \mathrm{N} 118^{\circ} 23^{\prime} 50^{\prime \prime} \mathrm{E}\right)$, located where a steep stream from Mt. Victoria $(1,726 \mathrm{~m})$ comes out to a large plain in Narra, Sulu Sea-side of the island. This new species was abundant in the pool below the first major fall with many cyprinids and gobies but absent in the reaches above it which are occupied by sicydiine gobies including Sicyopus zosterophorus (Bleeker) and Lentipes palawanirufus Maeda \& Palla, and eels of the genus Anguilla Schrank (unidentified to species level). The new species was also found in a creek in front of the Barangay Hall of Estrella Village (9'21'28"N 118 24'58"E), drawing from the stream below Estrella Falls. The stream flows into Malatgao River. When we surveyed a site in the middle reaches of the Malatgao River $\left(9^{\circ} 20^{\prime} 16.7^{\prime \prime} \mathrm{N} 118^{\circ} 27^{\prime} 27.0^{\prime \prime} \mathrm{E}\right)$, no Rhinogobius were found there. The water at Estrella Falls was cool even during the hottest dry season (May) in this region (water temperature was $26.5^{\circ} \mathrm{C}$ when measured on 13 May, 2016), while water in the Malatgao River was warmer (appeared to be nearly $30^{\circ} \mathrm{C}$ although we did not measure).

Etymology. The type locality of the new species is Estrella Falls in Barangay Estrella Village. Therefore, the new species is named as Rhinogobius estrellae, derived from Estrella, and the Latin suffix $-e$.

\section{Rhinogobius tandikan Maeda, Kobayashi \& Palla, new species}

[New English name: Tandikan goby]

(Figs. 1, 3, 6-8; Tables 2-6)

Material examined. Thirteen males and 16 females from Cayulo River, Bahile, Puerto Princesa City, Palawan Island in the Philippines. 
Holotype. NSMT-P 140093, male (43.6 mm SL), 1 June 2018, coll. K. Maeda, H. Kobayashi, and H. P. Palla.

Paratypes. NSMT-P 140094, female (45.7 mm SL), 31 May 2018 coll. K. Maeda, H. Kobayashi, and H. P. Palla; URM-P 49307-49315, 7 males (36.1-46.9 mm SL) and 2 females (37.3-38.9 mm SL), 31 May 2018 coll. K. Maeda, H. Kobayashi, and H. P. Palla; URM-P 49316-49323, 2 males (40.8-44.8 mm SL) and 6 females (35.6-45.2 mm SL), same data as holotype; WPU-PPC-P 60-64, 5 females (30.8-36.5 mm SL), 31 May 2018 coll. K. Maeda, H. Kobayashi, and H. P. Palla; WPU-PPC-P 65-69, 3 males (43.6-46.1 mm SL) and 2 females (39.6-41.3 mm SL), same data as holotype.

Diagnosis. Pectoral fin with 16 or 17 rays. Nape and posterior part of occipital region covered by cycloid scales; scaled area extending anteriorly to around a vertical line through posterior margin of preopercle or a little posterior to this line. Longitudinal scales 29-34, predorsal scales 5-13. Number of vertebrae 26. Cephalic sensory pore system usually with $\mathrm{B}^{\prime}, \mathrm{C}, \mathrm{D}(\mathrm{S}), \mathrm{E}, \mathrm{F}, \mathrm{H}^{\prime}, \mathrm{K}^{\prime}, \mathrm{L}^{\prime}, \mathrm{M}^{\prime}, \mathrm{N}$, and $\mathrm{O}^{\prime}$, but often lacking one or both side(s) of pore C. Transverse rows of sensory papillae on cheek. In preservative, lateral and dorsal sides of body without clear meshlike markings, obscure markings on cheek, and upper half of pectoral fin with dark brown band vertically across proximal part. In life, pectoral-fin base with a bright white vertical band reaching near bottom of fin.

Description. Body nearly cylindrical anteriorly and somewhat compressed posteriorly. Abdomen of male often thin. Head depressed and larger in male than female (head length 32.1-37.4 vs 30.8-33.4\% of SL; Fig. 3). Eyes located dorsolaterally. Mouth terminal and oblique with thick upper and lower lips. Anterior tips of upper and lower jaws almost even or upper jaw slightly protruding beyond lower jaw. Posterior end of upper jaw always exceeding a vertical line through anterior margin of eye. Mouth larger in male than female (upper-jaw length 13.3-20.9 vs 10.1-12.7\% of SL; Fig. 3). Anterior nostril short tubular, posterior nostril a pore. Cephalic sensory pore system usually with $\mathrm{B}^{\prime}, \mathrm{C}, \mathrm{D}(\mathrm{S}), \mathrm{E}, \mathrm{F}, \mathrm{H}^{\prime}, \mathrm{K}^{\prime}$, and $\mathrm{L}^{\prime}$ in oculoscapular canal and $\mathrm{M}^{\prime}, \mathrm{N}$, and $\mathrm{O}^{\prime}$ in preopercular canal, but 9/29 specimens lacking one pore C, 7/29 specimens lacking both pores C, 4/29 specimens lacking one pore E, 1/29 specimen having two pores $\mathrm{E}$ on one side, $4 / 29$ specimens having pore $\mathrm{G}$ on one side, $1 / 29$ specimen having pores $\mathrm{G}$ on both sides, and 5/29 specimens lacking one pore N. One specimen having combined pores $\mathrm{K}^{\prime}$ and $\mathrm{L}^{\prime}$ on one side (to be a groove without roof). Arrangement of cutaneous sensory papillae of head shown in Fig. 7. Cheek having two longitudinal rows of papillae and 3-6 transverse rows both between eye and upper longitudinal row and between upper and lower longitudinal rows. Vertebrae 10+16=26 ( $n=10)$, P-V 3/II II I I 0/9 ( $n=10)$.

All males had damage to the caudal fin, except holotype; 10/16 female specimens with damaged caudal fin (Figs. 1, 3). Other fins of male and female sometimes damaged also. First dorsal fin with six spines supported by six pterygiophores. Second dorsal fin usually with one spine and eight soft rays. First and second dorsal-fin bases separated each other by a small interval ( $0.2-4.4 \%$ of SL). First dorsal fin rounded, usually almost semi-circular; posterior tips of fin (tips of fourth to sixth spines) not reaching second dorsal fin origin ( $N=9)$, just touching base of second dorsal-fin spine $(\mathrm{n}=12)$, or exceeding base of second dorsal-fin spine but not reaching base of first soft ray of second dorsal fin $(n=8)$. Anal fin usually with one spine and eight soft rays, but 4/29 specimens with one spine and seven soft rays. Caudal fin usually with 17 segmented rays but 3/29 specimens with 16 segmented rays, including 11 $(n=1), 12(n=6), 13(n=15)$, or $14(n=22)$ branched rays (unknown in four specimens due to fin damage); posterior margin rounded in non-damaged individuals. Male having larger second dorsal and anal fins than female (second dorsal-fin length $33.8-43.6$ vs $29.5-35.3 \%$ of SL and anal-fin length 30.2-38.3 vs 26.7-32.7\% of SL), and nondamaged male with larger caudal fin than female (Fig. 3). Pectoral fin with 16 or 17 rays (Table 2). Pelvic fin with one spine and five soft rays; pelvic fins joined together to form a cuplike disk with fleshy bilobed frenum. Posterior tip of pelvic fin located below middle of first-dorsal-fin base.

Ctenoid scales covering lateral side of body and dorsal and ventral sides of caudal peduncle. Nape and posterior part of occipital region covered by cycloid scales; scaled area extending anteriorly around vertical line through posterior margin of preopercle (above pore $\mathrm{H}^{\prime}$ ) or to a little posterior to this line (above area between pores $\mathrm{H}^{\prime}$ and $\mathrm{K}^{\prime}$ ). Other regions in head naked. Belly and first dorsal-fin base covered with cycloid scales. A few cycloid scales also present on trunk behind pectoral fin, along bases of second dorsal, anal, and caudal fins, and on proximal part of caudal fin. Pectoral-fin base and breast (prepelvic area) probably naked (at least invisible without staining by arizarin red; see Suzuki et al. 2016). Longitudinal scales 29-34 (usually 30 or 31), transverse scales 8-10 (usually 9 or 10), transverse scales in caudal peduncle always 7, and predorsal scales 5-13 (Tables 3-5).

Colour in preservative (Fig. 1): Background of head and body brown dorsally and laterally and cream ventrally. Snout with obscure dark brown stripe connecting upper lip and eye. Cheek often with two obscure, dark brown intermittent lines. Posterior margin of opercle fringed by dark brown vertical band. Pectoral-fin base blackish except cream or pale brown bottom. Four to eight dark brown transverse bars or round blotches aligned along lateral 
midline of body. First and second dorsal fins pale grey with 3-7 brown horizontal stripes on proximal and middle parts, but anterior half of first dorsal fin lacking this marking. Anal fin greyish brown but light brown proximally. Caudal fin pale grey or greyish brown with 6-11 dark brown vertical bands, but dorsal and ventral parts lacking these bands. Pectoral fin pale greyish brown with a dark brown vertical band proximally on upper half. Pelvic fin greyish brown.

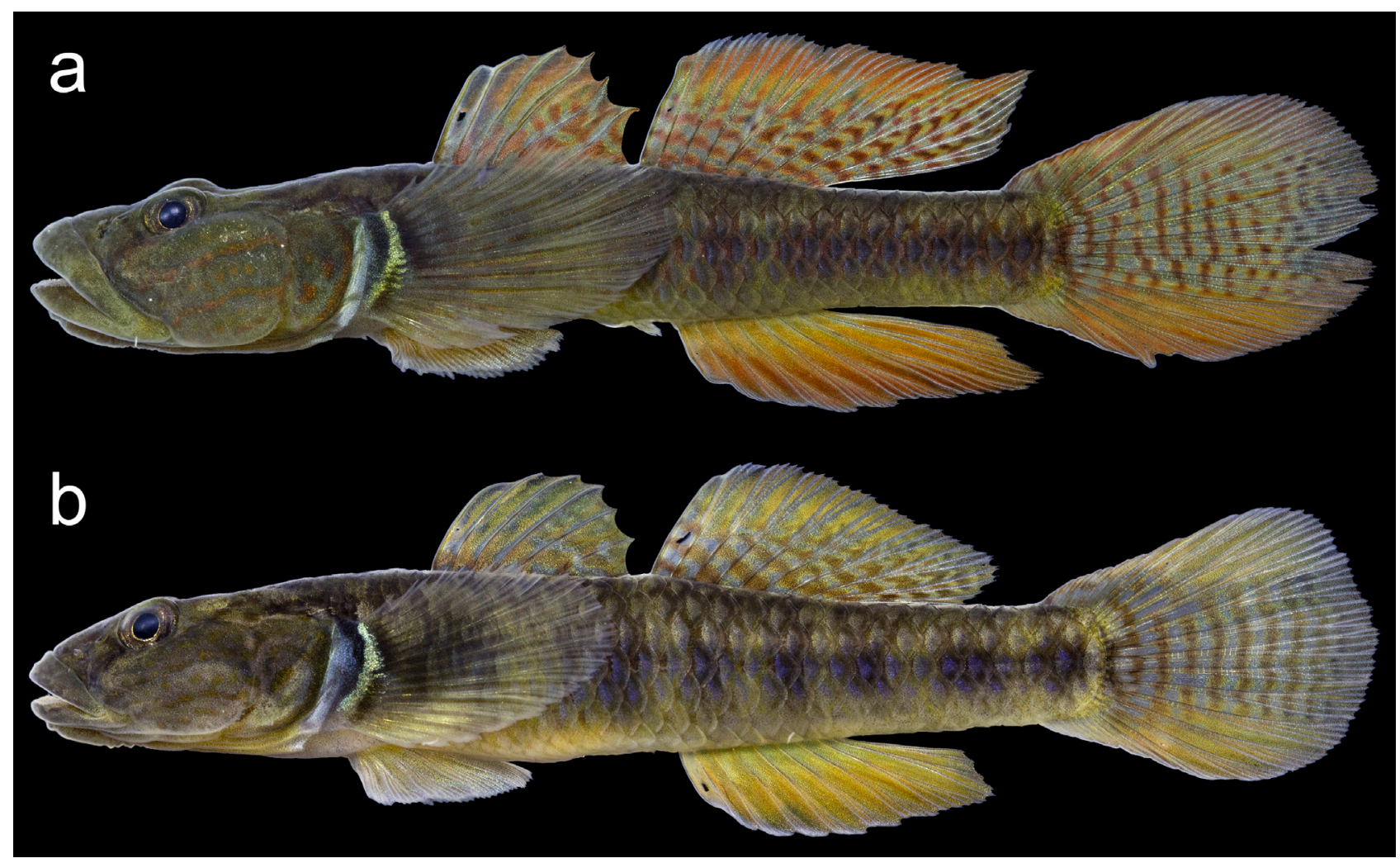

FIGURE 6. Rhinogobius tandikan immediately after fixation. a, NSMT-P 140093, holotype, male, 43.6 mm SL; b, URM-P 49316, paratype, female, $44.8 \mathrm{~mm}$ SL (photo by K. Maeda).

Colour in life (Fig. 8): Background of head and body olive green or yellowish grey. Snout with reddish brown stripe connecting upper lip and eye. Cheek with two reddish brown longitudinal intermittent lines and several reddish brown spots. Posterior margin of opercle fringed by reddish-brown vertical band. Pectoral-fin base black or dusky with a large greyish blue blotch anteriorly, and with a bright white vertical band posteriorly. Four to eight, dark brown transverse bars or round blotches aligned along lateral midline of body. Irregularly arranged dark brown markings dorsally on body. Centre of lateral scales tinged with sky blue. First and second dorsal fins light yellowish brown with 3-7 dark brown horizontal stripes on proximal and middle parts and reddish brown on distal part, but anterior half of first dorsal fin reddish brown without clear marking. Anal fin reddish brown or orange but yellowish proximally. Caudal fin reddish brown dorsally and ventrally and whitish with 6-11 dark reddish-brown transverse bands on middle part. Pectoral fin translucent but proximal parts of some ventral rays white. Pelvic fin reddish brown proximally and light grey distally.

Distribution. Rhinogobius tandikan is endemic to Palawan Island. It was found only in the Cayulo River, Bahile, northern part of Puerto Princesa City. The Cayulo River is a small stream (length approximately $4 \mathrm{~km}$ including $1 \mathrm{~km}$ of an estuary) flowing into Ulugan Bay on South China Sea-side of the island. The stream system is surrounded by mountains of about 200-400 m above sea level. Cayulo Falls, composed of a series of small waterfalls, is located at the middle eaches of this stream $\left(10^{\circ} 02^{\prime} 12^{\prime \prime} \mathrm{N} 118^{\circ} 45^{\prime} 03^{\prime \prime E}\right)$. Rhinogobius tandikan was found at both the lower and upper reaches of this waterfall, as well as pools in the middle of the falls. The new species was abundant in this site with many other goby species, cyprinids, and a jungle perch species.

Etymology. Tandikan is a local name of Palawan peacock-pheasant, Polyplectron napoleonis Lesson, known as a symbol of Puerto Princesa City. The new goby species is named Rhinogobius tandikan, as it has blue markings on the body, suggestive of the plumage of the Palawan peacock-pheasant, and as the type locality is located in the northern part of Puerto Princesa City. The new specific name is a noun in apposition. 


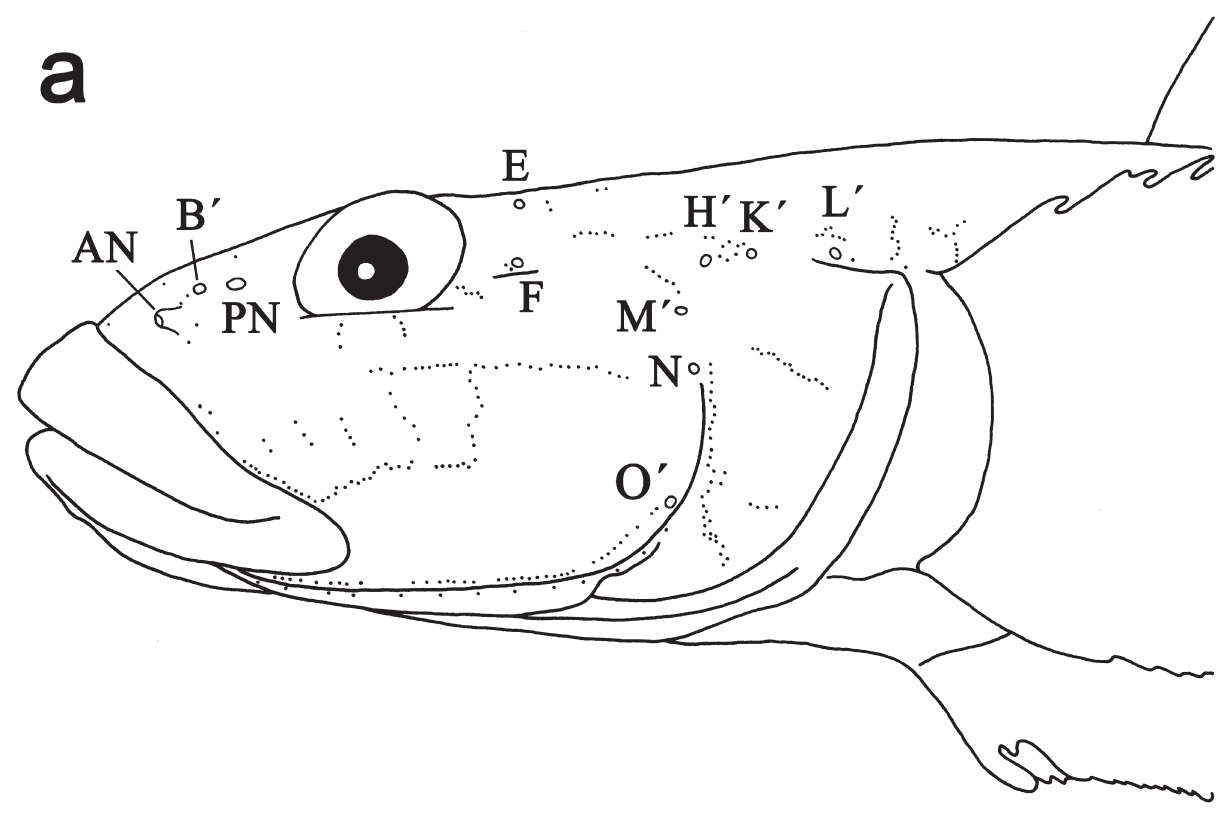

b
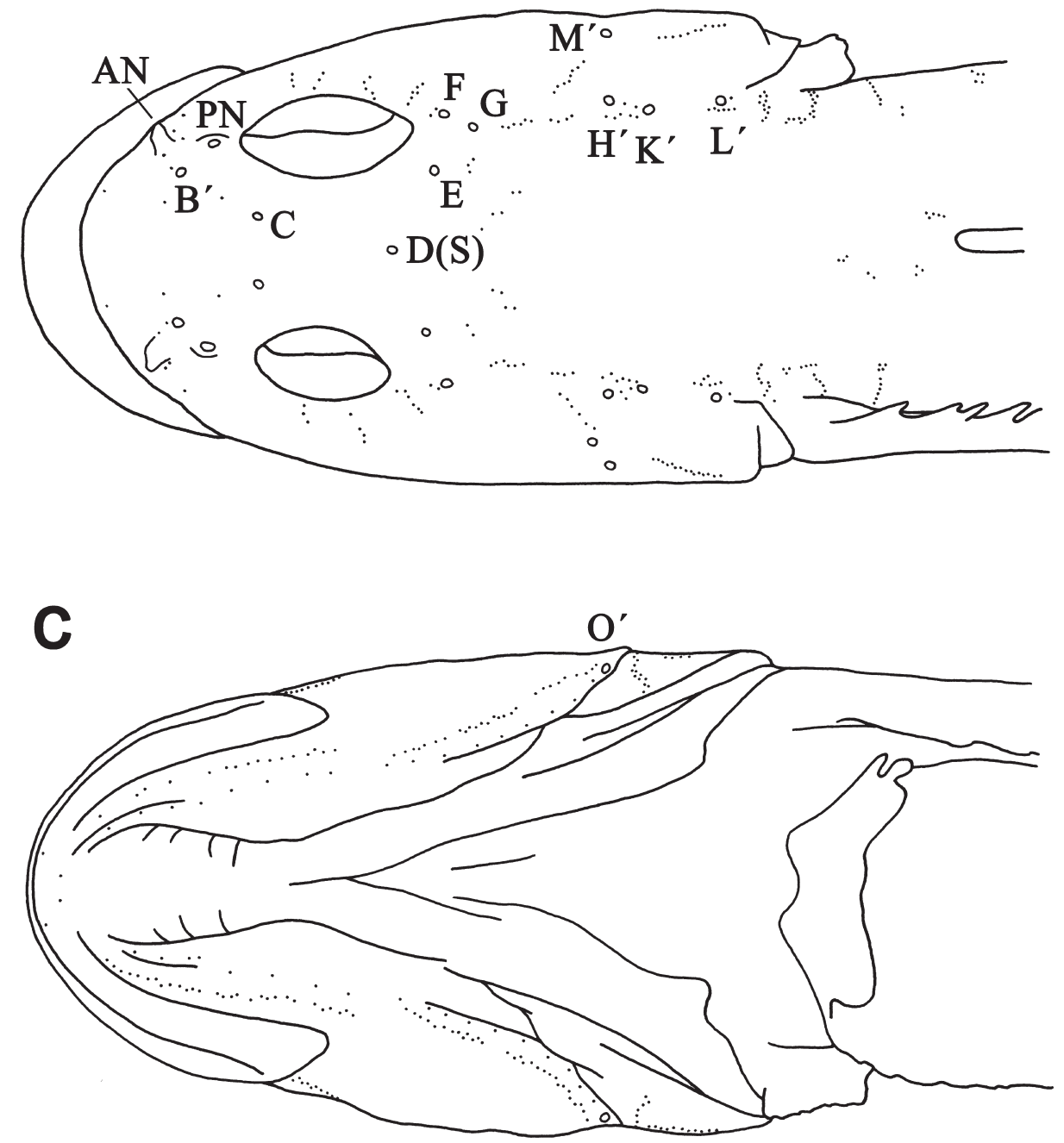

FIGURE 7. Arrangement of cephalic sensory pores and cutaneous sensory papillae in Rhinogobius tandikan (URM-P 49307, paratype). a, lateral view; b, dorsal view; c, ventral view. AN, anterior naris; PN, posterior naris. 


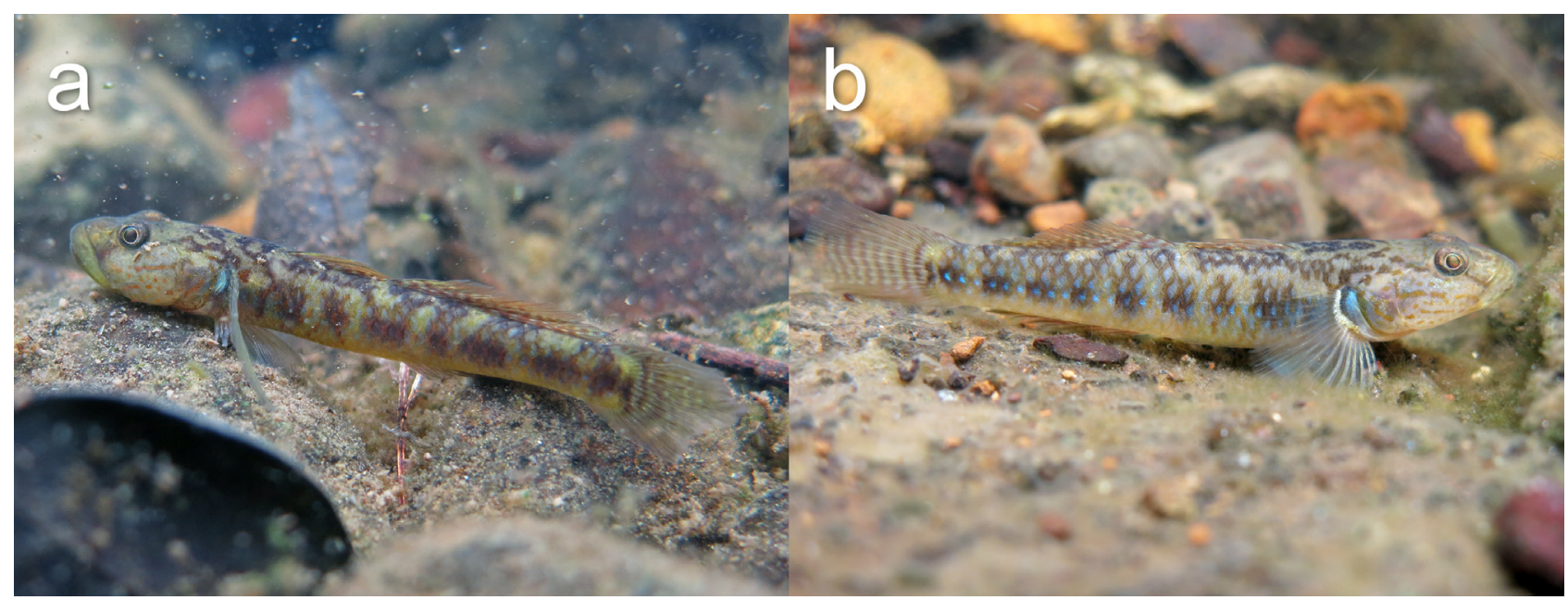

FIGURE 8. In situ underwater photographs of Rhinogobius tandikan in Cayulo River, Palawan. a, male, 31 May 2018 ; b, female, 1 June 2018 (photo by K. Maeda).

TABLE 6. Morphometrics of Rhinogobius estrellae and Rhinogobius tandikan expressed as a percentage of standard length. $\mathrm{D}_{1}$, first dorsal fin; $\mathrm{D}_{2}$, second dorsal fin; $\mathrm{A}$, anal fin; $\mathrm{C}$, caudal fin; $\mathrm{P}_{1}$, pectoral fin; $\mathrm{P}_{2}$, pelvic fin.

\begin{tabular}{|c|c|c|c|c|c|c|}
\hline & \multicolumn{3}{|c|}{ R. estrellae } & \multicolumn{3}{|c|}{ R. tandikan } \\
\hline & Holotype & Paratypes & Paratypes & Holotype & Paratypes & Paratypes \\
\hline & Male & Male & Female & Male & Male & Female \\
\hline Number of specimens & 1 & 7 & 16 & 1 & 12 & 16 \\
\hline Standard length (mm) & 40.6 & $37.3-40.7$ & $33.2-45.3$ & 43.6 & $36.1-46.9$ & $30.8-45.7$ \\
\hline Head length & 33.5 & $33.9-36.0$ & $30.3-32.9$ & 37.4 & $32.1-35.1$ & $30.8-33.4$ \\
\hline Snout length & 10.6 & $11.5-12.7$ & $9.0-10.7$ & 13.5 & $10.5-12.8$ & $9.4-11.1$ \\
\hline Eye diameter & 6.7 & $6.3-7.4$ & $6.9-7.8$ & 6.4 & $5.7-7.2$ & $5.6-7.7$ \\
\hline Postorbital length of head & 17.0 & $16.9-17.7$ & $14.8-17.0$ & 18.3 & $15.8-17.6$ & $15.7-17.2$ \\
\hline Upper-jaw length & 15.5 & $14.1-16.1$ & $10.5-11.9$ & 20.9 & $13.3-17.2$ & $10.1-12.7$ \\
\hline Body depth at $\mathrm{P}_{2}$ origin & 18.5 & $16.5-18.0$ & $15.7-19.7$ & 17.4 & $14.5-17.8$ & $15.5-18.8$ \\
\hline Body depth at A origin & 16.3 & $14.9-16.9$ & $14.8-17.9$ & 16.1 & $13.6-16.6$ & $15.7-18.8$ \\
\hline Depth at caudal peduncle & 12.8 & $11.5-12.7$ & $10.8-12.8$ & 12.2 & $10.1-11.9$ & $10.5-12.6$ \\
\hline Length of caudal peduncle & 24.9 & $24.0-25.1$ & $23.2-27.5$ & 23.2 & $23.1-26.4$ & $24.3-27.4$ \\
\hline Predorsal length & 39.4 & $39.3-41.4$ & $37.5-40.4$ & 41.5 & $38.7-41.1$ & $37.3-40.4$ \\
\hline Preanal length & 56.2 & $55.2-57.6$ & $54.7-59.2$ & 59.6 & $55.4-58.3$ & $54.5-57.3$ \\
\hline Length of $D_{1}$ base & 18.5 & $16.4-19.2$ & $16.6-20.9$ & 19.3 & $17.3-19.7$ & $17.9-21.2$ \\
\hline $\mathrm{D}_{1}$ length & 20.0 & $19.8-22.9$ & $19.1-21.1$ & 22.7 & $20.4-22.8$ & $19.2-21.6$ \\
\hline $\begin{array}{l}\text { Interval between } \mathrm{D}_{1} \text { and } \mathrm{D}_{2} \\
\text { bases }\end{array}$ & 1.2 & $0.3-3.7$ & $1.4-3.9$ & 0.2 & $0.4-2.3$ & $0.3-4.4$ \\
\hline Length of $\mathrm{D}_{2}$ base & 19.5 & $16.5-18.5$ & $16.5-18.9$ & 18.1 & $17.1-19.4$ & $16.6-19.1$ \\
\hline $\mathrm{D}_{2}$ length & 38.2 & $34.6-38.7$ & $27.7-30.2$ & 42.7 & $33.8-43.6$ & $29.5-35.3$ \\
\hline Length of A base & 16.5 & $15.4-17.1$ & $13.7-17.7$ & 14.9 & $14.0-16.2$ & $14.3-15.6$ \\
\hline A length & 33.7 & $31.3-33.1$ & $24.2-29.3$ & 38.3 & $30.2-37.0$ & $26.7-32.7$ \\
\hline $\mathrm{C}$ length & 29.6 & $28.6-31.7$ & $24.4-28.0$ & 34.9 & $9.3-33.8$ & $8.4-28.2$ \\
\hline
\end{tabular}

Comparison. Rhinogobius similis Gill, 1859 is the only species previously known in the genus having transverse rows of sensory papillae on cheek (Suzuki et al., 2016), and our two new species share this unique feature with $R$. similis. However, the two species in Palawan are distinguished from $R$. similis in having fewer rays in the pectoral fin (14-17 vs 18-19), predorsal squamation composed of cycloid scales (vs ctenoid scales), anterior-most 
dorsal scale located around a vertical line through posterior margin of the preopercle or more posteriorly (vs dorsal squamation reaching anteriorly near the posterior margin of the eye), and proximal part of the caudal fin covered by cycloid scales (vs by ctenoid scales).

Rhinogobius estrellae shares many characters with $R$. tandikan, but the former differs from the latter by having fewer pectoral-fin rays (usually 15 vs 16-17; Table 2), fewer scale counts (longitudinal scales 27-31 vs 29-34, predorsal scales 3-11 vs 5-13; Tables 3, 5), and colourations of the body. In preservative, $R$. estrellae has dark brown mesh-like markings on the lateral and dorsal sides of the body (vs rather uniformly brown in $R$. tandikan), three dark brown stripes on the snout and cheek (vs often obscure), and a dark brown vertical band on the proximal part of the upper and middle pectoral-fin rays except lower 2-6 rays (vs this band restricted to upper half of the fin). In life, $R$. estrellae has a more reddish body than the yellowish or olive green $R$. tandikan, and the former has a bright white vertical band restricted to the upper and middle parts of the pectoral-fin base while this band reaches nearly the bottom of the fin in $R$. tandikan. Arrangements of the cephalic sensory pore system are basically the same between the two species, but $R$. estrellae more often lacks pore $\mathrm{E}$ on one or both sides than in $R$. tandikan (12/24 vs 5/29) while R. tandikan more often lacks pore $\mathrm{C}$ on one or both sides than in R. estrellae (16/29 vs $7 / 24)$.

In addition to the transverse rows of sensory papillae on cheek (present vs absent), there are many differences between the two new species from Palawan and three other Philippine species, $R$. carpenteri Seale, 1910, R. bucculentus (Herre, 1927), and R. philippinus (Herre, 1927), such as numbers of the vertebrae (26 vs 27-29), first-dorsalfin pterygiophores (usually 6 vs usually 7), first-dorsal-fin spines (usually 6 vs usually 7 in R. bucculentus and 6 or 7 in R. carpenteri and R. philippinus), pectoral-fin rays (14-17 vs 17-20), having fewer scales in the longitudinal scales (27-34 vs 35-43), in the transverse scales ( $8-10$ vs $12-18)$, and in the transverse scales in caudal peduncle (7 vs 9-11), and presence of scales on belly behind the pelvic fins (vs absent in R. carpenteri and R. bucculentus). The latter three species are distributed in Luzon, northern Philippines (see Discussion).

Molecular phylogenetic analysis. In the ML phylogenetic tree using the aligned 16,409 bp of mitochondrial genomes (Fig. 9), the species in Rhinogobius were divided into two robust clades. One clade included $R$. similis and the two new species from Palawan, while all other species belonged to another clade. Six specimens of $R$. estrellae and four specimens of $R$. tandikan formed each well-supported monophyletic clade and were sister species to each other. Rhinogobius similis was a sister to this pair.

\section{Discussion}

We observed that males of $R$. tandikan were often skinny and almost always had heavy damages to the fins. They could be exhausted by caring their nests and eggs, and the damage could be the result of fighting against conspecific males or against intruders to their nest during the spawning season. On the other hand, Rhinogobius estrellae usually had no such damage, though we observed these two species in the same season (latter half of May). This observation suggested that $R$. tandikan may be more aggressive than $R$. estrellae during the spawning season. Otherwise, the spawning seasons may be different between the two species, because the habitat of $R$. estrellae was colder than that of $R$. tandikan. Surveys in other seasons could solve the cause of the damaged condition in $R$. tandikan.

Although we explored not only the type localities of $R$. estrellae and $R$. tandikan but also several other streams in central part of Palawan Island (in Puerto Princesa, Aborlan, Narra, and Quezon), Rhinogobius was absent except for the type localities of the two species. We have not surveyed all streams in this area, but it is considered that habitats of Rhinogobius are confined to a few special places, even if it is distributed in other streams. The sparse distribution in Palawan is very different from the status of Rhinogobius in the faunas on temperate and subtropical islands and coastal areas of the continent. In Okinawa Island in southern Japan for example, Rhinogobius is observed in almost every stream (Hirashima 1998; Maeda unpublished observation), and it seems to be one of the common taxa distributed in coastal streams and rivers in East Asia, as far as we know. Because the habitats of $R$. estrellae and $R$. tandikan are restricted to respective small ranges, they have risks of extinction. Alternation of the habitats caused by constructions of dams, roads, and leisure facilities, land developments for agriculture, etc. will threaten these endemic species.

Three species of the genus Rhinogobius are known from Luzon in the Philippines: they are $R$. carpenteri, $R$. bucculentus, and R. philippinus. Herre (1927) described a new genus Tukugobius Herre for these three species, but Tukugobius is currently regarded as a synonym of Rhinogobius after Herre (1933) reconsidered their taxonomy. 
Although some authors resurrected Tukugobius (see Mizuno 1960; Endruweit 2017), we consider it as a junior synonym of Rhinogobius in accordance with Suzuki et al. (2019). Among the three Luzon species, R. philippinus was described based on 14 specimens from Irid River, Santa Ines, Rizal Province and 22 specimens from Banaban River, Angat, Bulacan Province by Herre (1927), and he also noted that a collection in the Bureau of Science in Manila contained additional specimens of this species from Negros and Leyte islands as well as the other localities on Luzon. The central part of Palawan Island where we collected the two new species are located south of these islands. Since the specimens deposited at the Bureau of Science in Manila was destroyed during the World War II (Pietsch \& Anderson 1997; Kottelat 2013), and as the taxonomy of Rhinogobius and related genera was misconstrued in the early 20th century (Herre 1933), it is unclear if the materials from Leyte and Negros referred in Herre (1927) were really Rhinogobius or not. However, the discovery of Rhinogobius from Palawan in the present study suggests that the Rhinogobius could be distributed more widely in tropical islands in the Philippines than previously thought. It strongly indicates the necessity of more research on freshwater-fish fauna in islands in the Philippines.

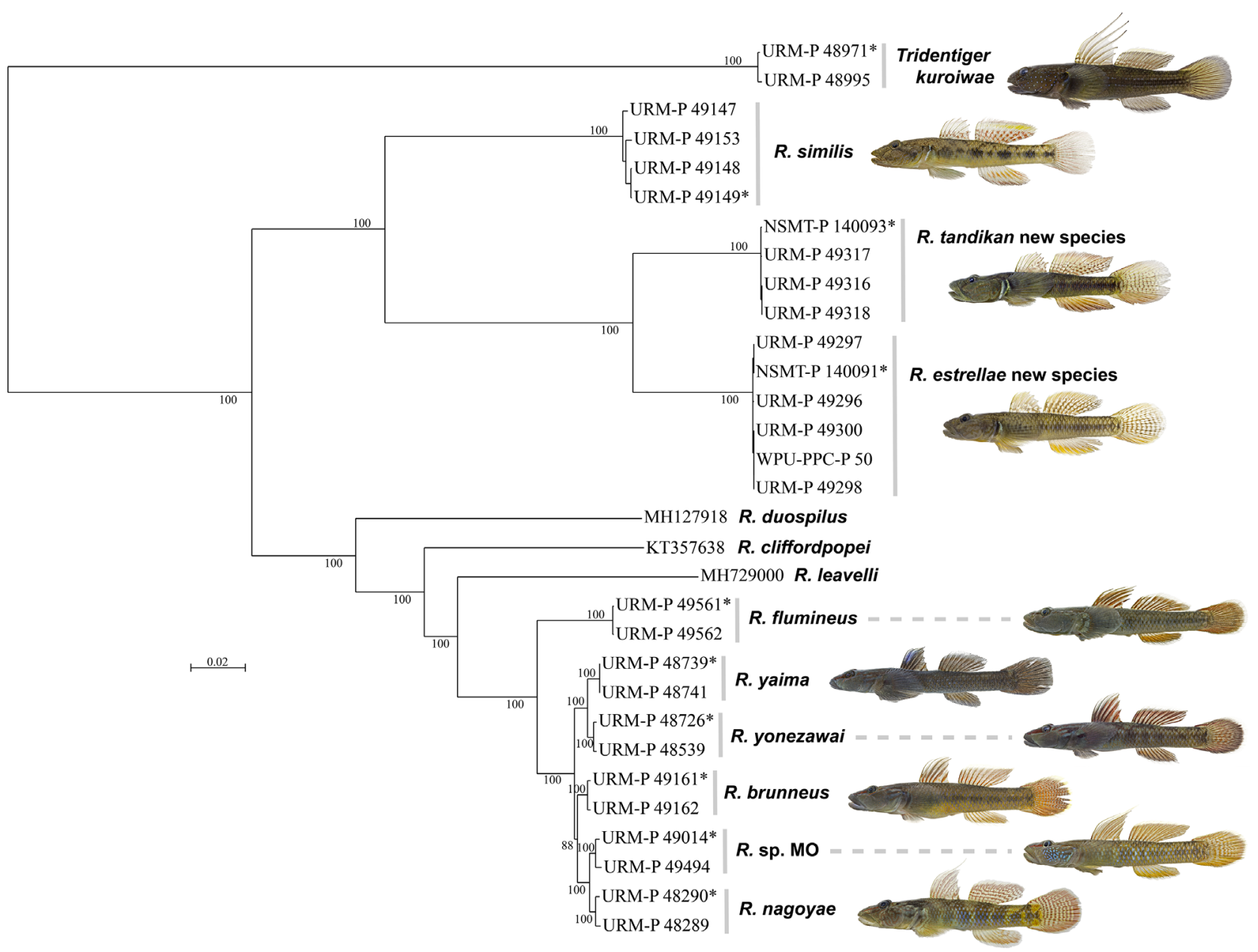

FIGURE 9. Maximum likelihood phylogenetic tree with 100 bootstraps using the aligned 16,409 bp of mitochondrial genomes in Rhinogobius including the two new species, $R$. estrellae and $R$. tandikan, with Tridentiger kuroiwae as an outgroup taxon. Material sequenced in the present study are shown with the catalogue numbers of the vouchers (beginning with NSMT-P, URMP, or WPU-PPC-P) and sequences from the International Nucleotide Sequence Database are shown with the accession numbers (R. cliffordpopei, R. duospilus, and R. leavelli). The scale bar indicates 0.02 substitutions per site. Pictures shown along with the species names are of the specimens with an asterisk.

Some authors who studied the phylogeny of the species in the genus Rhinogobius suggest that $R$. similis is the only species in the basal clade within the genus; it is in fact a sister species of all other species in the genus Rhinogobius examined by these authors (Masuda et al. 1989; Mukai et al. 2005, 2012; Yamasaki et al. 2015; Wang et al. 2019). Since we added the two new species, $R$. similis is no longer alone. Our mitochondrial DNA analysis indicated that $R$. estrellae and $R$. tandikan are additional members of the $R$. similis lineage. 
Rhinogobius similis has the widest distribution range in the genus from Japan and Korea to northern and central Vietnam (Maeda et al. 2015; Suzuki et al. 2016). It is distributed in Taiwan and Hainan (Wu \& Ni 1986; Chen \& Shao 1996), but absent in the Philippines except for introduced populations in Tikub Lake and Laguna de Bay, Luzon (Labatos Jr \& Briones 2014). Rhinogobius estrellae and R. tandikan in Palawan are considered to be relicts of their common ancestor with $R$. similis, which probably had a more widespread distribution.

\section{Comparative material}

Rhinogobius bucculentus: CAS-SU 26366, 6 specimens, 44.2-61.0 mm SL, Magat River, Bayombong, Nueva Vizcaya, Luzon Island, Philippines, 27 May 1931, coll. A. W. C. T. Herre [this material was referred to in Herre (1934)].

Rhinogobius carpenteri: CAS-SU 26367, 10/27 specimens, 27.9-55.8 mm SL, Trinidad River, Baguio, Luzon Island, Philippines, April 1931, coll. A.W. C. T. Herre [this material was referred to in Herre (1934)].

Rhinogobius philippinus: CAS-SU 38601, 5 specimens, 39.3-52.8 mm SL, Oriwong Toll Gate, Nueva Vizcaya, Luzon Island, Philippines, 2 June 1940, col. A. W. C. T. Herre (identified by Herre).

Rhinogobius similis: URM-P 48996, 48997, 2 specimens, 49.3-55.5 mm SL, Aritsu-gawa, Okinawa Island, Japan, 18 February 2015, coll. K. Maeda; URM-P 49147-49149, 3 specimens, 48.3-56.2 mm SL, Aritsu-gawa, Okinawa Island, Japan, 6 April 2015, coll. K. Maeda; URM-P 49153, 1 specimen, 52.4 mm SL, Taiho-oh-kawa, Okinawa Island, Japan, 16 April 2015, coll. K. Maeda. Data in Suzuki et al. (2016) was also used for the Comparison.

\section{Acknowledgements}

Samplings and surveys in Palawan were conducted under a Memorandum of Agreement for joint research between Okinawa Institute of Science and Technology Graduate University (OIST) and Western Philippines University (WPU). We thank Elsa P. Manarpaac, Lota A. Creencia, Benjamin J. Gonzales (WPU), Jonathan Dorfan, Hiroyo Clemente (OIST), Filipina B. Sotto, and Joeppette J. Hermosilla (University of San Carlos) for their support of this collaboration. We are grateful to Nelson P. Devanadera, Nino Rey C. Estoya, Beth Lagrada, Aira Bayron, and Aiza Nunez (Palawan Council for Sustainable Development, PCSD) for providing a Wildlife Gratuitous Permit (No. 2016-09, 2018-16) and a Wildlife Export Certification (No. 16-03, 2018-03); Lucena D. Demaala (Municipality of Narra), Lucilo R. Bayron (Puerto Princesa City), Rosalina Cañaveral (Barangay Estrella Village), and Carlos L. Quirante (Barangay Bahile) for providing a Prior Informed Consent Certificate, and all local residents who supported our surveys. We appreciate Gento Shinohara, Masanori Nakae (NSMT), Kei Miyamoto (Okinawa Churashima Foundation), David Catania, and Mysi Hoang (CAS) for loan and/or registration of the specimens, Toshifumi Saeki (Rivus, Okinawa) for support to collect specimens of R. yaima for the phylogenetic analysis, Mayumi Kawamitsu (OIST) and all members of the Sequencing Section in OIST for support to the library preparation and sequencing for mitochondrial DNA analysis, Elizabeth Speyer (OIST) for useful suggestions to improve the manuscript, and Vincent Laudet (OIST) for his kind support for this study. We would like to thank Helen K. Larson and an anonymous reviewer for their valuable comments to improve the manuscript. This study was supported by JSPS KAKENHI Grant Numbers 16K07492 and 21K06296 and by the Okinawa Institute of Science and Technology Graduate University.

\section{References}

Akihito Prince, Hayashi, M. \& Yoshino, T. (1984) Suborder Gobioidei. In: Masuda, H., Amaoka, K., Araga, C., Uyeno, T. \& Yoshino, T. (Eds.), The fishes of the Japanese Archipelago, English edition. Tokai University Press, Tokyo, pp. $236-238$.

Capella-Gutiérrez, S., Silla-Martínez, J.M. \& Gabaldón, T. (2009) trimAl: a tool for automated alignment trimming in largescale phylogenetic analyses. Bioinformatics, 25 (15), 1972-1973.

https://doi.org/10.1093/bioinformatics/btp348

Chen, I.-S. \& Shao, K.-T. (1996) A taxonomic review of the gobiid fish genus Rhinogobius Gill, 1859, from Taiwan, with de- 
scription of three new species. Zoological Studies, 35 (3), 200-214.

Endruweit, M. (2017) Neotype designation for Rhinogobius carpenteri Seale 1910, and its placement in Tukugobius Herre 1927 (Teleostei: Gobiidae). Zootaxa, 4277 (4), 549-560.

https://doi.org/10.11646/zootaxa.4277.4.5

Gill, T.N. (1859) Notes on a collection of Japanese fishes, made by Dr. J. Morrow. Proceedings of the Academy of Natural Sciences of Philadelphia, 11, 144-150.

Herre, A.W.C.T. (1927) Gobies of the Philippines and the China Sea. The Philippine Bureau of Science Monographic Publications of Fishes, 23, 1-352, pls. 1-30.

Herre, A.W.C.T. (1933) On the genera Ctenogobius, and Rhinogobius Gill, Tukugobius Herre, and Drombus Jordan and Seale. Science, 78 (2021), 265. https://doi.org/10.1126/science.78.2021.265.a

Herre, A.W.C.T. (1934) The fishes of the Herre 1931 Philippine Expedition with descriptions of 17 new species. Notes on Fishes in the Zoological Museum of Stanford University 1: The fishes of the Herre Philippine Expedition of 1931. Newspaper Enterprise Ltd., Hong Kong, 106 pp.

Hirashima, K. (1998) Distribution and early life history of Rhinogobius brunneus complex in Okinawa Island, Japan. Master's thesis. Graduate School of the University of the Ryukyus, Okinawa, 49 pp., 3 tabs, 74 figs.

Hirashima, K. \& Tachihara, K. (2000) Embryonic development and morphological changes in larvae and juveniles of two landlocked gobies, Rhinogobius spp. (Gobiidae), on Okinawa Island. Japanese Journal of Ichthyology, 47 (1), $29-41$. https://doi.org/10.11369/jji1950.47.29

Huang, S.-P. \& Chen, I.-S. (2007) Three new species of Rhinogobius Gill, 1859 (Teleostei: Gobiidae) from the Hanjiang basin, southern China. Raffles Bulletin of Zoology, Supplement 14, 101-110.

Huang, S.-P., Chen, I.-S. \& Shao, K.-T. (2016) A new species of Rhinogobius (Teleostei: Gobiidae) from Zhejiang Province, China. Ichthyological Research, 63 (4), 470-479.

https://doi.org/10.1007/s10228-016-0516-9

Iida, M., Kondo, M., Tabouret, H., Maeda, K., Pécheyran, C., Hagiwara, A., Keith, P. \& Tachihara, K. (2017) Specific gravity and migratory patterns of amphidromous gobioid fish from Okinawa Island, Japan. Journal of Experimental Marine Biology and Ecology, 486, 160-169. https://doi.org/10.1016/j.jembe.2016.09.011

Katoh, K. \& Standley, D.M. (2013) MAFFT multiple sequence alignment software version 7: Improvements in performance and usability. Molecular Biology and Evolution, 30 (4), 772-780. https://doi.org/10.1093/molbev/mst010

Kondo, M., Maeda, K., Hirashima, K. \& Tachihara, K. (2013) Comparative larval development of three amphidromous Rhinogobius species making reference to their habitat preferences and migration biology. Marine and Freshwater Research, 64 (3), 249-266.

https://doi.org/10.1071/MF12234

Kottelat, M. (2013) The fishes of the inland waters of Southeast Asia: a catalogue and core bibliography of the fishes known to occur in freshwaters, mangroves and estuaries. Raffles Bulletin of Zoology, Supplement 27, 1-663.

Labatos Jr, B.V. \& Briones, N.D. (2014) Freshwater fishes of Tikub Lake, Tiaong, Quezon, Philippines. Asian Journal of Biodiversity, 5 (1), 41-53.

https://doi.org/10.7828/ajob.v5i1.480

Liao, T.-Y., Huang, W.-C., Iizuka, Y., Chou, M.-T. \& Shiao, J.-C. (2020) Facultative amphidromy and pelagic larval duration plasticity of Rhinogobius formosanus (Teleostei, Gobioidei). Zookeys, 951, 91-107. https://doi.org/10.3897/zookeys.951.50429

Maeda, K. \& Tachihara, K. (2010) Diel and seasonal occurrence patterns of drifting fish larvae in the Teima Stream, Okinawa Island. Pacific Science, 64 (2), 161-176. https://doi.org/10.2984/64.2.161

Maeda, K., Tran, H.D. \& Tan, H.H. (2015) Discovery of a substantial continental population of the subfamily Sicydiinae (Gobioidei: Gobiidae) from Vietnam: Taxonomic revision of the genus Stiphodon from the western South China Sea. Raffles Bulletin of Zoology, 63, 246-258.

Masuda, Y., Ozawa, T. \& Enami, S. (1989) Genetic differentiation among eight color types of the freshwater goby, Rhinogobius brunneus, from western Japan. Japanese Journal of Ichthyology, 36 (1), 30-41. https://doi.org/10.11369/jji1950.36.30

Mizuno, N. (1960) Study on a freshwater goby, Rhinogobius similis Gill, with a proposition on the relationships between landlocking and speciation of some freshwater gobies in Japan. Memoirs of the College of Science, University of Kyoto, Series B, 27, 97-115.

Mukai, T., Nakamura, S., Suzuki, T. \& Nishida, M. (2005) Mitochondrial DNA divergence in yoshinobori gobies (Rhinogobius species complex) between the Bonin Islands and the Japan-Ryukyu Archipelago. Ichthyological Research, 52 (4), 410-413. https://doi.org/10.1007/s10228-005-0295-1

Mukai, T., Hirashima, K., Furuhashi, M., Furuta, R., Yodo, T. \&Nakanishi, N. (2012) Distribution of yoshinobori gobies (Rhinogobius kurodai and related species) in the irrigation ponds in southern Suzuka, Mie Prefecture, Japan, and their phyloge- 
netic analysis. Bulletin of the Biogeographical Society of Japan, 67, 15-24.

Nagao Natural Environment Foundation (2021) Fishes of the Indochinese Mekong. Nagao Natural Environment Foundation, Tokyo, xii $+546 \mathrm{pp}$.

Nakabo, T. (2002) Fishes of Japan with pictorial keys to the species. English Edition. Tokai University Press, Tokyo, 1749 pp.

Peng, Y., Leung, H.C.M., Yiu, S.M. \& Chin, F.Y.L. (2012) IDBA-UD: a de novo assembler for single-cell and metagenomic sequencing data with highly uneven depth. Bioinformatics, 28 (11), 1420-1428. https://doi.org/10.1093/bioinformatics/bts174

Pietsch, T.W. \& Anderson, W.D. (1997) Collection building in ichthyology and herpetology. American Society of Ichthyologists and Herpetologists, Lawrence, Kansas, 593 pp.

Pietsch, T.W., Amaoka, K., Stevenson, D.E., MacDonald, E.L., Urbain, B.K. \& Lopez, J.A. (2001) Freshwater fishes of the Kuril Islands and Adjacent Regions. Species Diversity, 6, 133-164. https://doi.org/10.12782/specdiv.6.133

Sabaj, M.H. (2019) Standard symbolic codes for institutional resource collections in herpetology and ichthyology: An Online Reference. Version 7.1. 21 March 2019. American Society of Ichthyologists and Herpetologists, Washington, D.C. Available from: https://asih.org/standard-symbolic-codes (accessed 12 September 2021)

Seale, A. (1910) New species of Philippine fishes. The Philippine Journal of Science, Section A, 4, 491-543, pls. 1-13.

Serov, D.V., Nezdoliy, V.K. \& Pavlov, D.S. (2006) The freshwater fishes of central Vietnam. KMK Scientific Press Ltd., Moscow, $364 \mathrm{pp}$.

Stamatakis, A. (2014) RAxML version 8: a tool for phylogenetic analysis and post-analysis of large phylogenies. Bioinformatics, 30 (9), 1312-1313. https://doi.org/10.1093/bioinformatics/btu033

Suzuki, T., Shibukawa, K., Senou, H. \& Chen, I.-S. (2016) Redescription of Rhinogobius similis Gill 1859 (Gobiidae: Gobionellinae), the type species of the genus Rhinogobius Gill 1859, with designation of the neotype. Ichthyological Research, 63 (2), 227-238. https://doi.org/10.1007/s10228-015-0494-3

Suzuki, T., Kimura, S. \& Shibukawa, K. (2019) Two new lentic, dwarf species of Rhinogobius Gill, 1859 (Gobiidae) from Japan. Bulletin of the Kanagawa Prefectural Museum (Natural Science), 48, 21-36. https://doi.org/10.32225/bkpmnh.2019.48_21

Tan, H., Yang, Y., Zhang, M. \& Chen, X. (2020) The complete mitochondrial genome of Rhinogobius duospilus (Gobiidae: Gobionellinae). Mitochondrial DNA Part B, 5 (3), 3424-3425. https://doi.org/10.1080/23802359.2020.1823279

Tsunagawa, T. \& Arai, T. (2008) Flexible migration of Japanese freshwater gobies Rhinogobius spp. As revealed by otolith Sr: Ca ratios. Journal of Fish Biology, 73 (10), 2421-2433. https://doi.org/10.1111/j.1095-8649.2008.02089.x

Tsunagawa, T., Suzuki, T. \& Arai, T. (2010) Otolith Sr:Ca ratios of freshwater goby Rhinogobius sp. TO indicating absence of sea migrating traits. Ichthyological Research, 57 (3), 319-322. https://doi.org/10.1007/s10228-010-0158-2

Wang, D., Dai, C., Li, Q., Li, Y. \& Liu, Z. (2019) Complete mitochondrial genome and phylogenic analysis of Rhinogobius cliffordpopei (Perciformes, Gobiidae). Mitochondrial DNA Part B, 4 (2), 2473-2474. https://doi.org/10.1080/23802359.2019.1637287

Wu, H. \& Ni, Y. (1986) Gobioidei. In: Chinese Academy of Fishery Sciences (Ed.), The freshwater and estuaries fishes of Hainan Island. Guangdong Science and Technology Press, Guangzhou, pp. 259-314.

Yamasaki, Y.Y., Nishida, M., Suzuki, T., Mukai, T. \& Watanabe, K. (2015) Phylogeny, hybridization, and life history evolution of Rhinogobius gobies in Japan, inferred from multiple nuclear gene sequences. Molecular Phylogenetics and Evolution, 90, 20-33. https://doi.org/10.1016/j.ympev.2015.04.012

Zhang, F. \& Shen, Y. (2019) Characterization of the complete mitochondrial genome of Rhinogobius leavelli (Perciformes: Gobiidae: Gobionellinae) and its phylogenetic analysis for Gobionellinae. Biologia, 74 (5), 493-499. https://doi.org/10.2478/s11756-018-00189-5 